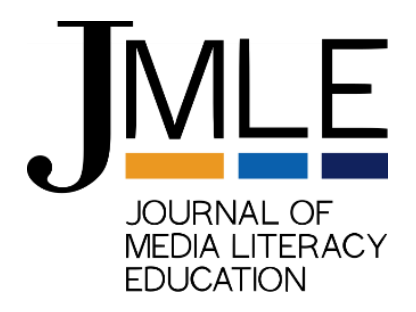

\title{
The secret sauce of online community of practice during COVID-19 pandemic: Nonviolent Communication
}

\section{○open AcCESS}

Voices from the Field - Peerreviewed article

Citation: Friesem, Y., \& Friesem, E. (2021). The secret sauce of online community of practice during COVID-19 pandemic: Nonviolent Communication. Journal of Media Literacy Education, 13(3), 133-136. https://doi.org/10.23860/JMLE-202113-3-11

\section{Corresponding Author:}

Yonty Friesem

yontyfilm@gmail.com

Copyright: () 2021 Author(s). This is an open access, peer-reviewed article published by Bepress and distributed under the terms of the Creative Commons Attribution License, which permits unrestricted use, distribution, and reproduction in any medium, provided the original author and source are credited. JMLE is the official journal of NAMLE.

Received: August 26, 2021

Accepted: December 2, 2021

Published: December 29, 2021

Data Availability Statement: All relevant data are within the paper and its Supporting Information files.

Competing Interests: The Author(s) declare(s) no conflict of interest.

\section{$\underline{\text { Editorial Board }}$}

\author{
Yonty Friesem \\ Columbia College Chicago, USA \\ Elizaveta Friesem \\ Media Education Lab, USA
}

\begin{abstract}
The challenges of work-family balance while being asked to move to remote instruction and engage students creatively have affected us all globally on multiple levels - from our professional identity, to our own health, mortality and purpose in life. The idea behind Nonviolent Communication (NVC) is that as Rosenberg (2015/1999) put it, it is a language that celebrates life. Applying these practices in a community building initiative of the Media Education Lab during the COVID-19 pandemic supported our community not only for their professional needs, but also and most importantly in their social and emotional resiliency to keep positive their family and work. This short article of voices from the field describe this secret sauce using the four elements of NVC (observation, sharing feeling, naming needs and requesting a feasible action) during the 2020 Virtual Viral Hangout (VVH) daily online meetings.
\end{abstract}

Keywords: online learning, social and emotional learning, professional development, Media Education Lab.

\section{Journal of Media Literacy Education}

THE OFFICIAL PUBLICATION OF THE

National AsSOCiation for MEdia literacy Education (NAMLE)

Online at www.jmle.org 


\section{INTRODUCTION}

At our final official Virtually Viral Hangout meeting on June 1, 2020, Michelle Ciccone, one of the regular participants and a contributing author of this collection, asked what was the secret sauce that made it work so effectively for so many people for such a long time. After all, the program was a daily online gathering, Mondays through Fridays, for 60 sessions over four months. Our answer was easy: Nonviolent Communication (NVC).

Many scholars have written about the direct impact of the COVID-19 pandemic and many more articles will follow. At our institution, Columbia College Chicago, instruction stopped for three weeks beginning March $13^{\text {th }}$ with the intention of allowing faculty time to move to online instruction. However, once the quarantine started we did not know what we were facing or how to cope with it. In our area of Chicago suburbs, on March $18^{\text {th }}$ the village of Oak Park, IL issued a Shelter-In-Place order. Other suburbs and eventually the governor of Illinois, like many other states, issued a state-wide executive order that also took effect on March $20^{\text {th }}$ including our children' day care. The quarantine was supposed to be a three-week safe measurement to reduce the spread of the new deadly virus. We were confined at home with our children as our teaching was on hold. From a place of uncertainty, anxiety and confusion came the collaborative idea of sharing, brainstorming and engaging with our community of media educators.

For eighteen years, the Media Education Lab ${ }^{1}$ has worked to advance the quality of media literacy education through research and community service. Over time, our work has helped to support a global community of media educators with online gatherings such as webinars, the Northeast Regional Media Literacy Conference, and other collaborative initiatives to advance the practice of media education. Given that the Media Education Lab consists of a strong network of educators who care about both the work and about each other, it seemed like a natural space to offer online community in a time of uncertainty for teachers. On a phone call, Renee Hobbs, founding director of the lab, Elizaveta Friesem, Research Fellow at the Lab, and Yonty as the associate director, brainstormed what can we offer to our global community at this time of uncertainty and crisis. We asked ourselves: At a time when everyone is trying to figure their next move, afraid of the future and puzzled with contracting information, what would be helpful for our colleagues?

We decided to consider Nonviolent Communication (NVC) in our solution. Elizaveta and Yonty include Dr. Marshall B. Rosenberg's method of NVC with our students. Rosenberg published the third edition of his book, Nonviolent communication: A language of life (2015/1999) right before his death at age 80. In his book, he offered the practice of NVC as a teaching method, a reconciliation practice, a form of conflict management, and a means to deepen meaningful relationships. Rosenberg named four stages of Nonviolent Communication that each one of the parties communicating should follow in the following sequence:

- Observe visible actions and heard language (without judgment or value attached)

- Share your feelings and emotions

- Name your needs

- Request a concrete and feasible action (with the understanding that it might be rejected).

Following this sequence, the listening party switches roles and follows the same order. After each party observes, shares, names, and requests, a deeper dialogue can emerge that increases understanding and leads to action. Nonviolent Communication can be used in a romantic relationship, a class discussion, a chat at work, or a civic deliberation in the community. Unlike a debate that puts the parties in collision and conflict, NVC practice promotes empathic listening that enables people to fully engage in the process of communication.

In the classroom, modeling NVC showcases how communication can be a deep, insightful, and collaborative process. In quarantine, as courses needed to be redesigned using digital pedagogies, Yonty decided to apply the four stages in the first fifteen minutes of every class session. This practice seemed like a good fit for a gathering of isolated educators seeking connection during uncertain times, and we decided to include it in our imagination of our online community. Since we were all scrambling to redesign courses for online learning, we also recognized a need to share digital tools and best practices with each other. But what to call this type of interaction? Renee suggested Virtual Viral Hangouts (VVH) and created a logo and sent an email to our community inviting them to join the first session on Monday, March 16, 2020. We committed to offer one session each day of the last week of March.

\footnotetext{
${ }^{1}$ www.mediaeducationlab.com
} 
Table 1 shows the topics and number of participants who attended the first week.

Table 1. Virtually Viral Hangouts, Week 1

\begin{tabular}{lll}
\hline DATE & TOPIC & PARTICIPANTS \\
\hline March 17 & $\begin{array}{l}\text { NVC as a } \\
\text { communication practice } \\
\text { NVC applied to } \\
\text { teaching and learning }\end{array}$ & 38 \\
March 19 & $\begin{array}{l}\text { Critical analysis of } \\
\text { pandemic meme }\end{array}$ & 39 \\
March 20 & $\begin{array}{l}\text { Intercultural dialogue } \\
\text { with Israeli educators }\end{array}$ & 66 \\
March 21 & Open sharing & 63 \\
\hline
\end{tabular}

By the end of the first week, it was obvious that VVH was a highly needed space for exchanges of ideas and practices. At a time when everyone was confined in their houses as schools and academic institutions were trying to manage the crises, VVH provided a place of both comfort and professional development. In the following section, we provide examples of the NVC sequence, as described by participants' reflections on their experience of the $\mathrm{VVH}$, which were collected on a Google Document ${ }^{2}$ at the end of May 2020 (after three month of daily Zoom meetings):

A. Observe without judgment. Participants discovered that, in a Zoom Room, we could experience intimacy and feelings of connection to people who were thousands of miles away if we maintain a spirit of trust and respect.

A group of educators began coming together, sharing - life in isolation, life on a screen, the beauty of life, the uncertainty of life, life away from a classroom, life without shoes, life within four walls. We laughed. We cried. We screamed. We danced. And then as all educators do, we all began teaching and learning. Each day brought nuggets...little stories that had to be told. (Kathleen Jackson)

VVH was a campfire in my wilderness. It was safe, I was accepted by all the cool kids there, and there was an adult in attendance, Renee, who made sure that our conversation was productive, fun, and inclusive... I learned about practices, platforms, and tools that I could explore to make my time in the wilderness valuable. Games, storytelling, analysis, and always... It was virtual. It wasn't "real". So, voices might break up. Faces might not be looking at me in a way I found reassuring. But that was the nature of the wilderness in which I had landed. I realized I could be in that wilderness for a while, so I'd better get used to it. And I slowly realized that, even once I found my way out of

2

https://docs.google.com/document/d/1nB4YTGfgkMLutcgle mWaqQFmasFNJOhnT7k_6WCKuVM/ it, this wilderness had become a playground to which I would want to return, again and again. (Maureen Tripp)

B. Sharing feelings. The coronavirus pandemic brought so much uncertainty into people's lives that it became truly therapeutic for us to acknowledge it and honor it through emotional self-expression, which was created as a daily part of each VVH session.

Though I am somewhat Zoom shy, I immediately felt at home. I had never studied media literacy in depth, though have contextualized some of its theories in my teaching... VVH inspired me to take more walks and see what was right in front of me, rather than hiding in place... I learned once again that during periods of sorrow, fear, and loss, one has to connect to others and fight inner demons. VVH helped me to push myself more emotionally and professionally, to recharge, reflect and share with better intention. (Debra Mandel)

I did not get many resources to use, per se. I got something more valuable and rare, practice in feeling good or ok at this awful time with a group of other embattled educators. And perhaps some modeling around how to make safe spaces for constructive sharing through crisis. (Michael RobbGrieco)

C. Naming needs. Having to explain your particular situation to another person who knows nothing about your family, work, or community context created a place of possibility and a reframing of needs and goals.

This group was something I really needed and it made the last 10 weeks much easier to deal with. When everyone around you is completely overwhelmed, it's great to have people to check in with, who may be overwhelmed too, which don't judge you. From a professional standpoint, it was fantastic to develop strong relationships with people in media literacy and to find individuals attempting positive things during this season. (Charles (Chuck) Hensey)

[...] I began to realize that I needed to prepare for what was going to be an unusual end to the school year... I had to puzzle out how I was going to do school or even do life in this new reality. During my reading, viewing, and searching I somehow stumbled upon an invitation to the Virtual Viral Hangout... It became an anchor for my day; the one positive thing I could count on each weekday. As the weeks marched on, I structured my day to hold that hour sacred. I almost cried the few times that something encroached on that time. It became something that I not only looked forward to, but something that I needed. (Lavon Jonson)

D. Request a concrete action. Participants experienced the concrete value of having a diverse community, as it enables and deepens appreciation for 
the efforts of colleagues and inspires our own continued work.

Even though we have a listserv available to us through Massachusetts School Library Association, I feel I have gained so much more from the time we worked in breakout rooms and having various folks present things they are well versed in. I am also walking away with renewed energy to focus on a project I started several years ago but have let it slide because I was busy with regular duties of my job. I know that what will help me get through this strange time is putting more of my energy in what truly excites me. (Ariel Dagan)

What am I going to do with what I've learned? Learned: How Renee Hobbs handles and manages a dynamic session that worked for all kinds of cultures, origins, ages, interests... How to check-in with emotions before anything else, the beauty of listening, of being yourself, playfulness, seriousness, values, professionalism, and not to forget any of it and its use and purpose during the fatidic situation we are all living in. In my case, I finish my masters in August. I want to keep in, in the career of decoding media. I want to develop an educational tool related to media literacy. (Marta Mejia Castaner)

Like any community of practice (Lave \& Wanger, 1991) there are limitations to the shared experience. The meetings were inclusive, and all were invited. Renee's facilitation welcomed each one to connect to others they did not know and create a sense of shared goals and community buildings. At the same time, the U.S. eastern time schedule did not work for people who live in Asia or Australia, nor for working parents who had kids at home. The issue of accessibility to the community of practice was not as much technical (eg. access through Zoom), but rather availability to participate in an hourlong session online. And yet, many participants highlighted the merit of this initiative in numerous positive accounts on social media through and personal emails, all of which thank the Media Education Lab and Renee Hobbs for facilitating this support for our community of media educators. The following five articles describe part of these experiences from a personal perspective of participation in Virtual Viral Hangout. Each author frames the participation in the community of practice as source of resiliency, community building, self-reflection, and professional development.

The challenges of work-family balance while being asked to move to remote instruction and engage students creatively have affected us all globally on multiple levels from our professional identity to our health, mortality, and purpose in life. The idea behind NVC is that, as Rosenberg put it, it is a language that celebrates life. Applying these practices in a community building initiative during the COVID-19 pandemic supported our community not only for their professional needs, but also - and most importantly - in their social and emotional resiliency to keep a positive outlook toward their family and work. Facing mortality and health concerns, digital divide and racial inequality, professional challenges and identity crisis, Virtually Viral Hangouts provided a courageous space to share, explore, and build together a professional answer to the growing challenges of Spring 2020. It is our hope that this special edition of Voices from the Field in the Journal of Media Literacy Education (JMLE) provide an insight and potential application for educators to apply NVC strategies to support their own community of practice as they build their own resiliency.

\section{REFERENCES}

Lave, J., \& Wenger, E. (1991). Situated learning. Legitimate peripheral participation. University of Cambridge Press.

Rosenberg, M.B. (2015). Nonviolent communication: A language of life (3rd Edition). Puddle Dancer Press. (Original work published 1999) 